\title{
Validity and Reliability: Early Childhood's Locomotor Capability Assessment Instruments
}

\author{
Yassinta Dwi Ayu Septyarini ${ }^{*}$, I Ketut Gading ${ }^{1}$, Putu Aditya Antara ${ }^{1}$ \\ ${ }^{1}$ Early Childhood Education Department, Faculty of Education, Universitas Pendidikan Ganesha, Indonesia \\ *Corrsponding author, Email: yassintaseptyarini@gmail.com
}

\begin{abstract}
Early childhood development in learning is significant. A child's development can be seen through the child's motor development. The child's motor can be divided into two, namely gross motor and fine motor. This research aims to develop early childhood's locomotor capability assessment instruments using development research with RDR (Research, Development, Research) development models. The child's locomotor is included in the development of gross motors. The children include leaping, jumping, and running. The instrument assessment of early childhood's locomotor capability at Kelompok ATaman Kanak-Kanak Gugus VI of Buleleng Regency was the study's subject by designing the blueprint and developing into a questionnaire with 12 statements. Experts in their field have tested each statement item so that an instrument's validity and reliability can be fulfilled. Developed instruments have very high validity and reliability, with scores of 0.91 and 0.81 . These results indicate that the instruments that have been developed can be applied and used as they should be in learning.
\end{abstract}

\section{Keywords: Assessment Instrument, Early Childhood's Locomotor Capability, Validity, Reliability}

\section{INTRODUCTION}

Early childhood education is a primary education that benefits from developing all aspects related to the child's development. At the age of five, the child's growth is a golden age for the child to create their abilities. Thus, preschoolers' generation occurs at the age of four to six years by providing a stimulus to stimulate the child's development. This statement is supported by [1], which states that children's education is a learning process that promotes the development of children's potential to solve problems in life.

There are other aspects such as physical-motor, language, cognitive, socio-emotional, moral-religious, and artistic aspects [2]. In the development of early childhood, the child has the opportunity to develop all aspects of themselves. One factor that data acquired is its motion skills. It is intended development to elements maturity and gesture control. According to [3], there is an element of mutual influence between body fitness, motion skills, and motion control so that it affects the movement skills of the child depending on the maturity of movement control in his body

One aspect of development in the growth of basic kindergarten skills is motor skills. Motor skills in children have a connection with the process of change seen in the activities carried out. Children can express feelings through combined movements. The combined actions can be done by allowing the child to imagine several stages, such as feeling, living, imaging, and giving shape [4]. Children generally perform gross motor gestures associated with the muscles of the child's hands, feet, and entire body such as crawling, running around, taming, jumping, hanging, throwing, catching, and maintaining balance [5].

Gross motor motion is related to the child's ability to move non-locomotor, which means it only involves a few parts of the body. Meanwhile, the locomotor movement is a movement that affects all aspects of the body, such as running, jumping, walking, throwing balls, and actions that use other motor activities. The locomotor movement is also characterized by the displacement of the place or position of the child. The locomotor training also requires stimulus, guidance, and exercise with parents' help at home. That way, the locomotor movement can be done smoothly with games that can be done outdoors to stimulate the child's locomotor activity.

Based on preliminary observations that have been conducted in Kelompok A Taman Kanak-Kanak Gugus VI in Buleleng Regency found several underlying 
problems. The problems found then will be researched to develop instruments used to assess the early childhood locomotors' capability of Kelompok A Taman KanakKanak Gugus VI in Buleleng Regency in the School Year $2019 / 2020$. The underlying point of the study is the problems in the field encountered such as factors that affect the movement of the child's locomotor as follow 1) factors in the child who do not want to move and have a quiet personality, 2) factors in the teacher at the time of learning that more focus on developing cognitive aspects, language and art, 3 ) factors of parents who don't interest in the exercise that has an impact on the gross motor movements that have been taught in school.

\section{METHOD}

This research is research and development (R\&D). This research implements research with the RDR development model or Research, Development, Research. Research with this model is a study developed by Borg and Gall [6]. This study's subject is the instrument of assessing the early childhood locomotors' capability of Kelompok A Taman Kanak-Kanak Gugus VI in Buleleng Regency. This development research aims to develop instruments to improve children's mobility capabilities by looking at feasibility with the validity test and assessment instruments' reliability. This study involved one measurement expert, one Early Childhood Education expert.

This research has three stages by applying the RDR development research model: development study stage, development stage, and product effectiveness test stage. Data collection is carried out using instruments in questionnaires or questionnaires given to teachers based on their circumstances. The questionnaire in this study aims to determine the feasibility of instruments viewed through the blueprint's accuracy, the suitability of indicators with concepts, and instrument items' suitability with indicators. Based on the needs in the field, so that formulated a blueprint of instruments to be developed in table 1 below:

Table 1. The Blueprint of the Early Childhood's locomotor Capability Assessment Instruments

\begin{tabular}{|c|c|c|c|c|}
\hline Variable & Dimensions & Indicators & Number of ltems & Item Number \\
\hline \multirow{6}{*}{$\begin{array}{l}\text { Feasibility of the } \\
\text { Early Childhood's } \\
\text { locomotor } \\
\text { Capability } \\
\text { Assessment } \\
\text { Instruments }\end{array}$} & \multirow[t]{2}{*}{ Running } & $\begin{array}{l}\text { Running with the more regular } \\
\text { movement and direction }\end{array}$ & 2 & 1,2 \\
\hline & & $\begin{array}{l}\text { Controlling the movement while } \\
\text { running }\end{array}$ & 2 & 3,4 \\
\hline & \multirow[t]{2}{*}{ Leaping } & $\begin{array}{l}\text { Leaping by lifting the feet to the front } \\
\text { and lower it fastly }\end{array}$ & 2 & 5,6 \\
\hline & & Leaping with a good coordination & 2 & 7,8 \\
\hline & \multirow[t]{2}{*}{ Jumping } & Jumping with the prescribed way & 2 & 9,10 \\
\hline & & $\begin{array}{l}\text { Jumping by using the feet } \\
\text { simultaneously }\end{array}$ & 2 & 11,12 \\
\hline \multicolumn{3}{|c|}{ Total Item } & \multicolumn{2}{|c|}{12 Items } \\
\hline
\end{tabular}

\section{RESULTS AND DISCUSSIONS}

Instrument development can be done by research, development, and product effectiveness testing. The development of regulatory instruments to assess the early childhood locomotors' capability of Kelompok A Taman Kanak-Kanak Gugus VI in Buleleng Regency in School Year 2019/2020 was designed based on the problems encountered in the field. Children's development at an early age depends heavily on the surrounding environment, which requires the child to get a stimulus to develop properly. The explanation is supported by [7], which states that children are the next generation of the nation, which must be looked after in its development.

Children aged 4-6 years are a process for children to develop in the golden age. Children aged 4-6 years' experience in significant motor development. At that age, the child experiences the effect of gross motor and fine motor. Gross motor is the development of a child's movements shown through running, jumping, climbing, and walking. In contrast, fine motor is offered through the child's ability to master beautiful muscle movements in skill, speed, and agility to use limbs such as hands and fingers.

One of the gross motors is locomotor motion. This motion is one of the basic movements found in the development of the child's motor. The locomotor movement is a basic motion that has a regularly composed movement [8]. So, the locomotor movement has an important role in the development of early childhood. The locomotor has the same activities as gross motors, such as jumping, walking, running, and jumping [9]. In its development, the child needs guidance and direction from parents and teachers to make every move has a good impact, one of which is health.

In school learning, teachers are designing learning that can stimulate children's motor development, such as locomotor movement. However, school learning requires a tool used to assess a child's development. Instruments are measuring instruments used in a study with the function to evaluate a research variable as well as to achieve research goals [10]. Thus, the development of 
instruments is necessary to assist teachers in carrying out learning related to early childhood development.

The data obtained based on preliminary observations are then developed into a blueprint of instrument and instrument items. The next stage is testing its validity and reliability to get valid and reliable results. Validity tests are carried out to test the accuracy of content and format on developed instruments [11]. Based on the validity test results, it can be accumulated, and the results are shown in Table 2 below:

Table 2. Recapitulation of Instrument relevance Results

\begin{tabular}{|c|c|c|c|}
\hline \multicolumn{2}{|c|}{$1^{\text {st }}$ Expert } & \multicolumn{2}{|c|}{$2^{\text {nd }}$ Expert } \\
\hline Relevant & Irrelevant & Relevant & 11 \\
\hline $1,2,3,4,5,6,7$, & - & $1,2,3,4,5,6,7,8,9$, & 10,12 \\
$8,9,10,11,12$ & & \multicolumn{1}{c}{ Irrevant } \\
\hline
\end{tabular}

Table 2 shows that $1^{\text {st }}$ and $2^{\text {nd }}$ experts have assessed the accuracy of instruments toward 12 questionnaires that have been developed. The first expert states that the twelve questionnaire items are relevant, while the second expert says that the questionnaire item in point 11 is irrelevant.

Based on table 2, it can be taken into account the validity of the contents of the early childhood's locomotor capability assessment instrument using Gregory's formula of 0.91 , which means the result is in a very high category. The result indicates that the assessment instruments that have been designed and developed have a very high level of validity to be used.

Furthermore, the assessment instrument is tested for reliability to determine the feasibility of each item. A Microsoft Excel 2010 application assists the reliability test of the instrument. Reliability test results can be seen in Table 3 below:

Table 3. Recapitulation of Experts' Assessment on Instrument Items

\begin{tabular}{|c|c|c|c|c|c|c|}
\hline \multirow{2}{*}{$\begin{array}{c}\text { Statement ltem } \\
\text { Number }\end{array}$} & \multicolumn{2}{|c|}{ Experts } & \multirow{2}{*}{$\begin{array}{l}\text { Number of } \\
\text { Scores }\end{array}$} & \multirow{2}{*}{$\mathbf{p}$} & \multirow{2}{*}{$\mathbf{q}$} & \multirow{2}{*}{$\mathbf{p q}$} \\
\hline & 01 & 02 & & & & \\
\hline 1 & 1 & 1 & 2 & 1 & 0 & 0 \\
\hline 2 & 1 & 1 & 2 & 1 & 0 & 0 \\
\hline 3 & 1 & 1 & 2 & 1 & 0 & 0 \\
\hline 4 & 1 & 1 & 2 & 1 & 0 & 0 \\
\hline 5 & 1 & 1 & 2 & 1 & 0 & 0 \\
\hline 6 & 1 & 1 & 2 & 1 & 0 & 0 \\
\hline 7 & 1 & 1 & 2 & 1 & 0 & 0 \\
\hline 8 & 1 & 1 & 2 & 1 & 0 & 0 \\
\hline 9 & 1 & 1 & 2 & 1 & 0 & 0 \\
\hline 10 & 1 & 1 & 2 & 1 & 0 & 0 \\
\hline 11 & 1 & 0 & 1 & 0.5 & 0.5 & 0.25 \\
\hline 12 & 1 & 1 & 2 & 1 & 0 & 0 \\
\hline Total Score $(\mathrm{X})$ & 12 & 11 & 21 & & & \\
\hline $\mathrm{X}^{2}$ & 11 & 121 & 441 & & & \\
\hline
\end{tabular}

Based on the recapitulation of the reliability test results, instrument assessment of the early childhood's locomotor capability can be accumulated as follows:
Table 4. The Accumulation of Instrument Reliability Score Assessment

\begin{tabular}{|c|c|c|}
\hline $\begin{array}{c}\text { Statement Item } \\
\text { Number }\end{array}$ & Experts & $\begin{array}{c}\text { Number of } \\
\text { Scores }\end{array}$ \\
\cline { 2 - 3 } & $\mathbf{0 1}$ & $\mathbf{0 2}$ \\
\hline$\Sigma \mathrm{pq}$ & & 0.5 \\
\hline $\mathrm{n}$ & & 12 \\
\hline $\mathrm{St} 2$ & & 2 \\
\hline $\mathrm{r} 12$ & & 0.81 \\
\hline
\end{tabular}

Based on the instrument scoring items' reliability calculation, the early childhood locomotors' capability of 
Kelompok A Taman Kanak-Kanak Gugus VI in Buleleng Regency in the school year 2019/2020 is on a very high criterion with a score of 0.81 . The result indicates that the instrument items have very high reliability. [12] opinion supports these reliability test results, which states that a measuring instrument is declared to have high reliability if it has high consistency.

In obtaining valid and reliable results, instrument development passes the development research stage with the RDR model. The first stage is the development study stage. At this stage, initial observations are carried out to obtain and collect information on related issues. The problem's results related to the early childhood's locomotor capability at Kelompok A Taman KanakKanak Gugus VI in Buleleng Regency. The problem is a source of information that will help design and develop at a later stage.

The second stage is the development stage. At the development stage, the information obtained is based on the preliminary results in the development study and then analyzed based on related data. At the stage of development, the thing that is done in preparing a blueprint of instruments related to the assessment of children's locomotor movements in kindergarten. The preparation of the blueprint then continued with the development of questionnaire items or questionnaires. The development of questionnaire items is continued by developing indicators based on aspects of the locomotor's capability.

The next stage in the development phase is to conduct non-test assessments using questionnaires that are for and filled by teachers following the ability of their students in kindergarten. In drafting a non-test assessment using a Likert scale, four categories are used to assess each available item. The four categories are score 4 for the Berkembang Sangat Baik (BSB) or category of Very Good Development, 3 for Berkemban Sesuai Harapan $(B S H)$ or the category of Growing as Expected, 2 for Mulai Berkembang $(M B)$ or the category of Start Developing, and 1 for Belum Berkembang $(B B)$ or the undeveloped category.

The final stage of development research with the RDR model is the product effectiveness test. At this stage is the last stage that aims to test the instrument scoring the children's locomotor capability at Kelompok A. Instruments that have been designed based on the problems found and developed into assessment items are then tested for feasibility. Experts conduct due diligence by providing an instrument assessment sheet to determine the relevance of the assessment instrument that has been developed. The next stage in the product effectiveness test is to make improvements according to experts' advice and assessment on the instrument scoring the child's mobility capability to perfect the assessment instrument.
Bypassing a series of feasibility testing of children's locomotor capability that looks by the assessment instrument's validity and reliability, it can be said that the developed assessment instrument is worth to be used. Besides, based on the stages that have been followed in the research of RDR model development for the development of early childhood's locomotor capability assessment instrument at Kelompok A Taman KanakKanak Gugus VI in Buleleng Regency in the School Year $2019 / 2020$ has validity and reliability with very high criteria with a score of 0.81 for validity and 0.91 for product reliability.

The development of an instrument to be said to be feasible must meet the eligibility requirements. The requirements that must be met are reliable and valid. An instrument can be valid if it has high validity, but otherwise, it has low validity. The statement is supported by a statement from [13] that states that an instrument is valid if it can function according to measuring appropriately. While the other condition is reliable, an instrument can be trusted even though it has been tested on other objects. An instrument can be said to have high reliability if the measurement results are performed, showing the same results if tested to the same group with different periods [14].

The current research has the same results as previous research. The development of assessment instruments against the child's gross motor has very high validity and reliability based on validity and reliability tests and qualifying as a quality instrument. However, relevant research also shows that several items in the instrument need to be repaired to get results that suit them. Thus, the development of children's locomotor motion capability assessment instruments is indispensable by adjusting to the field's needs.

Based on test instruments' validity and reliability, assessing the early childhood's locomotor occupies a very high level, which means that this assessment instrument can be applied to kindergarten learning. The result shows that the instrument scoring the early childhood's locomotor capability at Kelompok A Taman Kanak-Kanak Gugus VI in Buleleng Regency has been developed to qualify as a quality instrument.

\section{CONCLUSION}

The validity and reliability test results of the early childhood's locomotor capability at Kelompok A Taman Kanak-Kanak Gugus VI in Buleleng Regency can be concluded that instrument assessment can be applied used in learning to measure the ability of children. The validity test results proved that the assessment instrument sits on very high validity criteria with a score of 0.91 . The reliability test results showed the same results that the child's locomotor motion assessment instrument had very high reliability with a score of 0.81 . Based on these results, teachers can use assessment instruments 
developed to support learning in early childhood. So that teachers can solve the problems underlying the development of this assessment instrument. The involvement of parents, as well as children, is also helpful in implementing this assessment instrument.

\section{REFERENCES}

[1] P. A. Antara, Pengembangan bakat seni anak pada taman kanak-kanak, Jurnal Ilmiah VISI PPTK PAUDNI 10(1) (2015) 29-34.

[2] Suyadi, Psikologi belajar PAUD, PT Bintang Pusaka Abadi, 2010.

[3] S. Santoso, et. al., Model pengembangan motorik anak, Depdiknas, 2002.

[4] P. A. Antara, Stimulasi metode permainan kreatif berdesain creative movement dalam menumbuhkan kemampuan spasial anak dengan mempertimbangkan budi pekerti, Jurnal Pendidikan Usia Dini 12(2) (2018) 301-310.

[5] R. M. Al Hakim, L. Rohmah, Pengembangan fisik motorik melalui gerak tari di kelompok B RA DWP UIN Sunan Kalijaga Yogyakarta, Golden Age Jurnal Ilmiah Tumbuh Kembang Anak Usia Dini 3(4) (2018) 269-286.

[6] E. Saputro, W. Mulyanto, N. E. Rusminto, Pengembangan bahan ajar menulis berbasis nilainilai kearifan local, Jurnal J-Simbol (Bahasa, Sastra, Dan Pembelajarannya) 2(14) (2014) 1-15.
[7] P. A. Antara, Implementasi pengembangan karakter anak usia dini dengan pendekatan holistik Jurnal Ilmiah VISI PGTK PAUD dan Dikmas 14(1) (2019)17-26.

[8] D. S. A. Wulan, Peningkatan kemampuan gerak lokomotor melalui permainan lari estafet modifikasi (penelitian tindakan di TK B jihan ulfani kecamatan medan marelan tahun 2014/2015) rangsangan Melakukan gerakan tubuh secara terkoordinasi untuk, Jurnal Pendidikan Usia Dini, 2015, pp. 163 180.

[9] Sujiono, Hakikat perkembangan motorik anak, Universitas Terbuka, 2010.

[10] Sugiyono, Metode penelitian pendidikan pendekatan kuantitatif, kualitataif dan R\&D, ALFABETA, 2013.

[11] I. M. Candiasa, Pengujian instrumen penelitian disertasi aplikasi iteman dan bigsteps, Undiksha, 2010.

[12] A. G. A Agung, Evaluasi pendidikan, FIP Undiksha, 2017.

[13] S. Azwar, Sikap manusia teori dan pengukurannya, Pustaka Pelajar, 2003.

[14] Z. Arifin, Evaluasi Pembelajaran, PT. Remaja Rosdakarya, 2009. 